\title{
PERAN KELOMPOK PEMBUDIDAYA IKAN (POKDAKAN) ACI BAHARI DALAM PEMBUDIDAYAAN IKAN BANDENG DI DESA PESISIR KECAMATAN GENDING KABUPATEN PROBOLINGGO
}

\author{
Mely Cahya Puspita ${ }^{1}$, Aryo Fajar Sunartomo, SP., M.Si. ${ }^{2}$ \\ ${ }^{1}$ Alumnus Jurusan Sosial Ekonomi Pertanian Universitas Jember \\ ${ }^{2}$ Staff Pengajar Jurusan Sosial Ekonomi Pertanian Universitas Jember \\ e-mail:cahyamely77@gmail.com
}

\begin{abstract}
Probolinggo Regency is one of the production centers for milkfish producers in East Java. Milkfish has a very good prospect to be developed in the agribusiness especially in fisheries subsector. One of milkfish cultivators group that is known to be active in Probolinggo Regency is Aci Bahari Fish Cultivators Group (Pokdakan). This research aimed to explain the role of Aci Bahari Fish Cultivators Group (Pokdakan) on the cultivation of milkfish in Pesisir Village of Gending District, Probolinggo Regency. The research area was determined by purposive method in Pesisir Village. The research used descriptive qualitative method. Determination of informant conducted by purposive sampling. The methods used in collecting data are interviews, observation, and documentation. Data analysis method used is Miles and Huberman model. The results of the research showed that (1) The role of Aci Bahari Pokdakan as a learning class included the formulation of learning needs, routine group meetings, learning motivation, learning processes and the activeness of the group. (2) The role of Aci Bahari Pokdakan as a vehicle for cooperation included the atmosphere of cooperation, the division of tasks, deliberation of problems, planning of providing production facilities and cooperation with other production parties. (3) The role of Aci Bahari Pokdakan as a production unit included decision making, preparation of the group needs, technology facilities, implementation of group agreements and increasing production sustainability.
\end{abstract}

Keywords: fish cultivators group, learning class, production unit, role, vehicle for cooperation

\section{PENDAHULUAN}

Menurut Andrianto (2005), sub sektor perikanan merupakan salah satu sumberdaya alam yang mempunyai prospek cerah bagi Indonesia dimasa yang akan datang. Hal itu dikarenakan perairan Indonesia meliputi $70 \%$ dari total wilayah yang dapat menghasilkan delapan juta ton ikan setiap tahun. Berdasarkan cara melakukannya, paling sedikit terdapat 2 jenis usaha yaitu tambak dan kolam ikan. Perikanan mengandung pengertian segala usaha penangkapan ikan laut maupun budidaya ikan serta pengolahan hingga proses pengolahan dan pemasaran hasil olahannya. Walaupun dari segi penggunaan teknologi dalam sub sektor perikanan Indonesia masih kurang maju dibandingkan negara lain, tetapi hasil perikanan Indonesia telah menyumbangkan produksi yang cukup besar untuk menunjang pendapatan negara. Perikanan budidaya terbagi dalam tiga bagian yaitu budidaya air tawar, budidaya air payau dan budidaya laut. Ikan bandeng dikenal sebagai ikan petualang yang suka merantau dikarenakan keberadaannya dapat hidup di jenis air mana pun. Ikan bandeng adalah salah satu komoditas primadona dari sub sektor perikanan dikarenakan memiliki prospek yang cukup tinggi. Ikan bandeng banyak disukai masyarakat karena merupakan salah satu bahan pangan yang bergizi yang mudah untuk diperoleh dan juga diolah. 
Tabel 1.1 Produksi Ikan Bandeng Menurut Kecamatan di Kabupaten Probolinggo (Kg) Tahun 2017

\begin{tabular}{llrrrrr}
\hline No & Kecamatan & TW 1 & TW 2 & TW 3 & \multicolumn{1}{l}{ TW 4 } & \multicolumn{1}{c}{ Jumlah } \\
\hline 1 & Paiton & 15.523 & 21.164 & 10.336 & 7.313 & 54.336 \\
2 & Kraksaan & 28.911 & 39.418 & 19.250 & 13.621 & 101.200 \\
3 & Pajarakan & 6.801 & 9.273 & 4.528 & 3.204 & 23.806 \\
$\mathbf{4}$ & Gending & $\mathbf{9 0 . 6 2 1}$ & $\mathbf{1 2 3 . 5 5 4}$ & $\mathbf{6 0 . 3 4 0}$ & $\mathbf{4 2 . 6 9 4}$ & $\mathbf{3 1 7 . 2 0 9}$ \\
5 & Dringu & 46.416 & 63.285 & 30.906 & 21.877 & 162.484 \\
6 & Sumberasih & 81.398 & 110.978 & 54.199 & 38.348 & 284.923 \\
7 & Tongas & 36.768 & 50.130 & 24.482 & 17.322 & 128.701 \\
\hline
\end{tabular}

Sumber : Dinas Perikanan dan Kelautan Kabupaten Probolinggo, 2015

Keterangan

\section{TW : Triwulan}

Kabupaten Probolinggo memiliki 24 Kecamatan,dan penghasil produksi ikan bandeng yang tertinggi ada di 7 kecamatan, salah satunya adalah kecamatan Gending. Hal tersebut dikarenakan Kecamatan Gending dekat dengan pantai utara yang menjadikan mayoritas masyarakatnya bekerja sebagai nelayan atau pembudidaya ikan. Hal tersebut terbukti dengan adanya data pada tabel 1.1 diatas bahwa produksi ikan bandeng di Kecamatan Gending di tahun 2017 termasuk kategori tertinggi yaitu sebesar $317.209 \mathrm{~kg}$. Jenis lahan yang paling banyak diusahakan adalah tambak ikan. Pokdakan Aci Bahari merupakan salah satu kelompok pembudidaya ikan yang dapat dikategorikan sebagai Pokdakan yang cukup aktif dalam upaya untuk memenuhi kebutuhan ikan khususnya ikan bandeng di Kabupaten Probolinggo.

Menurut Suwitaningrum dalam Putri (2015) menyatakan bahwa dengan bergabungnya petani atau petambak ke dalam kelompok tani dapat memberikan banyak manfaat, yaitu semakin cepatnya penyerapan ilmu pengetahuan dan teknologi baru, dapat meningkatkan orientasi pasar yang baik berkaitan dengan input maupun produk yang dihasilkan, serta dapat memanfaatkan secara lebih optimal seluruh sumberdaya yang tersedia. Para petambak yang masih skala kecil pada dasarnya lebih rentan mengalami kegagalan dibandingkan petambak yang bergabung dalam kelompok, hal ini dikarenakan kendala yang dihadapi oleh petambak tersebut. hanya ditangani sendiri. Bergabungnya petambak individu ke dalam kelompok pembudidaya ikan (Pokdakan) dengan pengelolaan yang baik, merupakan solusi bagi para petambak untuk dapat mengembangkan usahanya. Karakteristik Kelompok Pembudidaya Ikan (Pokdakan) yaitu kelompok yang dibentuk dari, oleh dan untuk pembudidaya ikan. Pokdakan mempunyai pembagian tugas dan tanggung jawab dan mempunyai kepentingan bersama.

Berdasarkan penelitian Benne dan Sheats (1948) menyimpulkan bahwa sebuah kelompok memiliki 3 tipe peran yaitu salah satunya adalah peran tugas, dimana anggota kelompok yang melakukan tugasnya untuk mencapai tujuan tertentu pada kelompok tersebut. Menurut peraturan Menteri Pertanian Nomor 82 tahun 2013 menyatakan bahwa fungsi atau peran Pokdakan terdiri dari tiga fungsi tugas yaitu kelas belajar, wahana kerja sama dan unit produksi. Penelitian ini 
menggabungkan dua teori tersebut dikarenakan peran pokdakan menurut Peraturan Menteri Pertanian mendukung teori peran tugas yang dikemukakan oleh Benne dan Sheats.

Manfaat Pokdakan terdiri dari manfaat teknis yang meliputi memudahkan pola pengaturan produksi, mempercepat proses alih teknologi dan memudahkan penyediaan sarana produksi serta manfaat sosial yang meliputi jaminan keamanan dalam berbudidaya, memperluas dan mempercepat pembelajaran. Besarnya potensi ikan bandeng yang dimiliki oleh Pokdakan Aci Bahari perlu diperhatikan bagaimana peran dari kelompok.

Pembentukan dan pembinaan kelompok tani perlu dilakukan secara berkesinambungan pada perubahan pola pikir petani dalam penerapan agribisnis dan untuk mewujudkan petani mandiri sebagai objek pembangunan pertanian melalui peran-peran yang telah dijalankan oleh kelompok tersebut. Tujuan dari penelitian ini adalah untuk menjelaskan peran kelompok pembudidaya ikan Aci Bahari dalam pembudidayaan ikan bandeng di Desa Pesisir Kecamatan Gending Kabupaten Probolinggo.

\section{METODE PENELITIAN}

Penelitian dilakukan di Desa Pesisir Kecamatan Gending Kabupaten Probolinggo dengan menggunakan purposive method. Lokasi tersebut dipilih atas pertimbangan-pertimbangan tertentu karena Desa Pesisir merupakan desa yang mayoritas penduduknya bermata pencaharian sebagai pembudidaya ikan dan memiliki potensi dalam usaha perikanan budidaya, khususnya komoditas ikan bandeng serta terdapat kelompok pembudidaya ikan yang aktif bernama Kelompok Pembudidaya Ikan (Pokdakan) Aci Bahari.

Metode penelitian yang digunakan adalah metode deskriptif kualitatif, yakni menjelaskan, meringkas berbagai kondisi, berusaha membuat gambaran atau lukisan secara sistematis, faktual dan akurat mengenai fakta-fakta serta hubungan antar fenomena yang diteliti (Bungin, 2007). Tujuan dari penggunaan metode ini untuk menjelaskan dan menggambarkan peran kelompok pembudidaya ikan (Pokdakan) Aci Bahari dalam pembudidayaan ikan bandeng di Desa Pesisir.

Penentuan informan pada penelitian ini menggunakan metode Purposive Sampling. Metode Purposive Sampling adalah metode yang digunakan sebagai langkah awal untuk menentukan informan kunci dengan cara memilih dengan melihat apakah informan dirasa dapat memberikan informasi yang sesuai dengan permasalahan penelitian (Singarimbun dan Effendi et al., 2012). Menurut penelitian Faisal dalam Satori, 2014. Menyatakan bahwa penentuan informan kunci tersebut hendaknya memenuhi kriteria sebagai informan awal yang membuka suatu informasi yang dibutuhkan. Berikut ini adalah kriteria yang harus ada pada informan kunci :

1. Mereka yang menguasai atau memahami sesuatu melalui proses enkulturasi, sehingga sesuatu itu bukan sekedar diketahui , tetapi juga dihayati.

2. Merupakan mereka yang masih sedang berkecimpung atau terlibat pada kegiatan yang tengah diteliti.

3. Mempunyai waktu yang memadai untuk dimintai informasi.

4. Penyampaian informasi oleh mereka yang tidak menyampaikan informasi hasil kemasannya sendiri.

5. Mereka yang lebih menggairahkan untuk dijadikan semacam guru atau narasumber bagi peneliti yang sebelumnya merupakan orang yang tergolong asing bagi peneliti

Kriteria yang digunakan dalam penentuan informan kunci adalah ketua kelompok pembudidaya ikan (Pokdakan) yang tergabung pada Pokdakan Aci Bahari di Kecamatan Gending Kabupaten Probolinggo. Ketua kelompok pembudidaya ikan juga digunakan sebagai acuan untuk menentukan informan berikutnya yaitu anggota kelompok tani. Informan yang dengan sengaja diambil yaitu 7 orang anggota kelompok dari Pokdakan Aci Bahari yang memahami betul mengenai berbagai kegiatan yang berlangsung dalam kelompoknya. 
Metode yang digunakan dalam mengumpulkan data primer adalah dengan menggunakan 3 metode yaitu wawancara, observasi dan dokumentasi (Sugiyono, 2014). Metode yang digunakan untuk melakukan wawancara adalah metode wawancara semi terstruktur. wawancara semi terstruktur termasuk dalam wawancara mendalam. Teknik ini dilakukan dengan bantuan pedoman wawancara, namun pelaksanaannya lebih bebas. Observasi yang digunakan dalam penelitian ini adalah observasi tanpa partisipasi. Observasi partisipasi pasif dilakukan ketika peneliti hanya berkedudukan sebagai pengamat kegiatan di lapang, tanpa terlibat langsung dalam kegiatan kelompok yang diamati. Metode dokumentasi dapat berupa literatur, artikel, jurnal serta situs di internet yang berkaitan dengan penelitian yang dilakukan. (Sugiyono, 2014).

Metode analisis data menggunakan model Miles dan Huberman. Menurut Miles dan Huberman dalam Sugiyono (2014), analisis data dalam penelitian kualitatif dilakukan ketika pengumpulan data berlangsung dan setelah pengumpulan data selesai dalam periode tertentu. Analisis data dilakukan secara interaktif dan terus menerus hingga data yang diperoleh telah jenuh. Analisis data dalam penelitian kualitatif terbagi menjadi beberapa tahap yaitu, reduksi data (data reduction), penyajian data (data display), dan menarik kesimpulan (conclusion drawing).

Uji keabsahan perlu dilakukan dalam penelitian kualitatif. Triangulasi adalah salah satu metode untuk mengatasi keraguan terhadap hasil yang diperoleh ketika penelitian dengan cara mengecek kembali. Menurut Sugiyono (2014), triangulasi adalah teknik pengumpulan data yang bersifat menggabungkan dari beberapa cara dan beberapa sumber yang telah ada. Triangulasi yang akan digunakan pada penelitian ini adalah triangulasi sumber yaitu mendapatkan data dari sumber yang berbeda namun menggunakan cara dan teknik yang sama dalam pengambilannya.

\section{HASIL DAN PEMBAHASAN}

Kegiatan pembudidayaan ikan bandeng yang dilakukan oleh Kelompok Pembudidaya Ikan (Pokdakan) Aci Bahari di Desa Pesisir Kecamatan Gending Kabupaten Probolinggo ini telah terbentuk sejak tahun 2014. Pokdakan Aci Bahari dikenal kelompok pembudidaya yang hanya membudidayakan ikan bandeng sebagai komoditas utamanya. Pokdakan Aci Bahari memiliki tujuan yang sama bersama dengan anggotanya yaitu meningkatkan kelancaran usaha anggota (pembudidaya ikan), meningkatkan kerjasama dan alih teknologi informasi diantara anggota dan mendukung terwujudnya pengembangan kawasan ekonomi khusus berbasis perikanan (minapolitan) di Kabupaten Probolinggo.

Menurut Forsyth (2010) menyatakan bahwa struktur kelompok adalah pola interaksi yang stabil antara anggota kelompok, yang berkaitan dengan bentuk pengelompokan, bentuk hubungan, perbedaan kedudukan antar anggota, pembagian tugas dan sebagainya. Kelompok juga berfungi dan terbentuk dari interaksi antar anggotanya. Kelompok juga dapat disebut sebagai jaringan kerja dari hubungan antar manusia dan sebuah kelompok hanya akan efektif jika kerjasama yang dilakukan antar anggota kelompok tersebut efektif. Ketika dua atau lebih individu bergabung untuk mencapai suatu tujuan, disaat itulah struktur kelompok berkembang. Interaksi yang terjadi antara anggota kelompok terbentuk dari peran-peran kelompok atau aturan-aturan dan norma-norma yang ada di dalam kelompok. Bahasan utama dalam perkembangan struktur kelompok adalah norma, peranan dan hubungan antar anggota kelompok itu sendiri.

Pokdakan Aci Bahari merupakan kelompok pembudidaya ikan yang memiliki struktur kelompok yang jelas yang ditandai dengan adanya interaksi yang baik antar sesama anggota, sehingga dari pola-pola interaksi tersebut terbentuklah hubungan yang kuat sehingga kelompok dapat didirikan berdasarkan tujuan yang sama. Pokdakan Aci Bahari saling bekerjasama dalam berbagai hal, seperti kerjasama dalam budidaya ikan bandeng, penanganan masalah atau kendala dalam budidaya bahkan alternatif upaya keberlanjutan produksi ikan bandeng. 


\section{Peran Pokdakan Aci Bahari Sebagai Kelas Belajar}

Forsyth (2010) menyatakan bahwa role differentiation adalah perbedaan peran dalam suatu kelompok, misal menjadi pemimpin atau pengikut. Dalam suatu kelompok tentulah tidak akan memiliki peran yang sama pada anggotanya. Ada yang berperan sebagai pemimpin sehingga dituntut untuk optimis. Meskipun bukan menjadi jaminan bahwa dengan status tertentu, setiap anggota di asosiasikan dengan sifat tertentu. Kecenderungan untuk menggolongkan dan mengembangkan peran-peran kelompok dalam menyelesaikan tugastugasnya, selain itu juga harus memastikan apakah kebutuhan hubungan dan kebutuhan interpersonal anggota kelompoknya telah terpenuhi.

Peranan merupakan aspek dinamis kedudukan (status). Apabila seseorang melaksanakan hak dan kewajibannya sesuai dengan kedudukannya maka dia menjalankan suatu peranan. Pembedaan kedudukan dengan peranan adalah untuk kepentingan ilmu pengetahuan. Keduanya tak dapat dipisahkan karena yang satu tergantung pada yang lain dan sebaliknya. Pentingnya peranan adalah karena ia mengatur perilaku seseorang. Peranan menyebabkan seseorang pada batas-batas tertentu dapat meramalkan perbuatan-perbuatan orang lain (Soekanto,1982).

\section{Perumusan Kebutuhan Belajar}

Kebutuhan belajar dalam kelompok tani memang sangat diperlukan dalam peran Kelompok Pembudidaya Ikan (Pokdakan) Aci Bahari dalam pembudidayaan komoditas ikan bandeng. Hal tersebut dikarenakan bahwa dengan kelompok itu mengetahui kebutuhan belajarnya sendiri, maka kelompok tersebut cenderung untuk membuat suatu kelas belajar dan menyusun kebutuhan belajar. Menurut Sutarto dalam penelitian Sulistiani (2011) menyatakan bahwa kebutuhan belajar adalah segala sesuatu kebutuhan baik individu maupun kelompok yang berupa keinginan atau kehendak untuk mengetahui atau memiliki pengetahuan, sikap dan keterampilan tertentu. Kebutuhan belajar di Pokdakan Aci Bahari cukup banyak disesuaikan dengan keadaan di lahan, baik itu materi belajar mengenai cara budidaya, proses perawatan dan juga cara menangani berbagai permasalahan yang dialami oleh masing-masing anggota kelompok.

Meskipun dalam setiap diadakannya forum diskusi selalu dihadiri oleh pihak Dinas Perikanan tetapi materi pembelajarannya tetap dirumuskan dan disiapkan oleh anggota kelompok Aci Bahari, karena menurut mereka, permasalahan yang ada di kelompok hanya kelompok tersebut yang mengetahui dengan jelas. Perumusan kebutuhan belajar di Pokdakan Aci Bahari diperoleh dari Dinas tetapi pengajuannya berawal dari kelompok karena permasalahan di lahan hanya kelompok yang memahami situasi dan kondisi.

Kemudian apabila ada sosialisasi dari Dinas Perikanan, materi disiapkan oleh panitia penyelenggara yaitu pihak dinas. Kebutuhan dan perencanaan belajar tersebut telah disiapkan jauh-jauh hari sebelum pertemuan rutin kelompok digelar. Pembahasan dalam kelompok juga dihadiri oleh pihak Dinas Perikanan, karena apabila dari pihak dinas tidak hadir maka akan terjadi kecemburuan antar anggota kelompok satu dengan yang lainnya. Tujuan dari adanya perumusan kebutuhan belajar inilah yang akan menjadikan kelompok bertambah sukses.

\section{Motivasi Belajar}

Motivasi belajar kelompok adalah rasa keinginan, dorongan yang kuat dan dirasakan muncul dalam diri manusia untuk memenuhi sejumlah kebutuhan dalam kehidupannya agar tujuan yang ingin dicapai dalam kelompok tersebut dapat tercapai dengan baik dan sesuai harapan. Motivasi belajar yang ada pada Pokdakan Aci Bahari telah dirasakan cukup baik oleh para anggotanya. Hal tersebut terlihat jelas ketika akan diadakan forum diskusi dalam pertemuan rutin kelompok, seluruh anggota selalu hadir dan antusias. Keantusiasan mereka dapat dilihat dalam tiap acara pertemuan rutin diskusi, mereka selalu membuat daftar 
pertanyaan dari berbagai masalah yang dialami di dalam kelompok. Hal yang mendorong Pokdakan Aci Bahari untuk semangat dalam belajarnya karena Pokdakan ini ingin terus berkembang dan maju dalam bidang budidaya ikan bandeng sehingga dapat selalu memproduksi ikan dalam jumlah yang tinggi dan berkualitas.

Tugas yang diberikan oleh Bapak Wahid selaku ketua Pokdakan sudah cukup adil dan dirasa saling meringankan antar anggota satu dengan yang lainnya sehingga tidak ada yang memberatkan. Tanda lainnya adanya motivasi kelompok yang tinggi juga karena pihak Dinas dan juga inspektorat selalu memantau keadaan Pokdakan Aci Bahari, yang kinerjanya selalu baik sampai saat ini.

\section{Pertemuan Rutin Kelompok}

Pertemuan rutin kelompok Aci Bahari yang diadakan setiap satu bulan sekali telah cukup menggambarkan bahwa Pokdakan Aci Bahari merupakan kelompok pembudidaya yang aktif. Pertemuan rutin yang diselenggarakan bertempat di rumah ketua kelompok, Bapak Haji Wahid dan terkadang diselenggarakan di pondok tambak yaitu ruang sekretariat Pokdakan Aci Bahari yang letaknya tidak jauh dari tambak milik Pokdakan Aci Bahari. Tiap pertemuan rutin selalu menghadirkan salah satu orang dari Dinas Perikanan. Pihak Dinas Perikanan tersebut datang dalam acara pertemuan rutin tersebut untuk meninjau perkembangan Pokdakan Aci Bahari dan membantu memberikan saran dan solusi apabila dibutuhkkan. Pertemuan rutin yang diselenggarakan kelompok telah cukup baik menurut para anggota Pokdakan Aci Bahari.

Pokdakan Aci Bahari sudah cukup sering dan baik karena setiap ada perkumpulan kelompok selalu menghadirkan dari pihak Dinas Perikanan, walaupun 1 orang staffnya. Hal tersebut bertujuan agar tidak terjadi kecemburuan sosial antar anggota dan ada jalan penengah apabila terjadi permasalahan di kelompok dan agar pihak Dinas Perikanan mengetahui progress kinerja dari Pokdakan Aci Bahari yang sudah berjalan dengan baik. Pertemuan rutin yang dilakukan oleh Pokdakan Aci Bahari dilangsungkan setiap bulan sekali, tempat berkumpul yang dipilih adalah di rumah ketua kelompok.

\section{Proses Belajar Kelompok}

Proses pembelajaran adalah proses yang di dalamnya terdapat kegiatan interaksi antara guru dengan siswa dan terjadi komunikasi timbal balik yang berlangsung dalam situasi edukatif untuk mencapai tujuan belajar. Proses belajar yang baik akan mendorong petani untuk dapat lebih mudah dalam penyerapan ilmu pengetahuan agar apa yang menjadi tujuannya dapat terwujud. Terdapat proses belajar yang biasa diterapkan oleh anggota Pokdakan Aci Bahari dan telah disampaikan oleh semua anggota kelompok yaitu proses belajar secara praktek langsung sehingga mereka akan lebih memahami apa yang benar-benar harus dilakukan ketika menyerap ilmu pengetahuan baru maupun di dalam menangani permasalahan yang kerap terjadi dalam proses budidaya bandeng. Pokdakan Aci Bahari menjalin kerjasama dengan penyuluh perikanan sebagai sumber informasi agar kelompok dapat berkembang dan juga membantu Pokdakan dalam mencari solusi terhadap permasalahan yang dihadapi oleh kelompok.

Pokdakan Aci Bahari berpacu pada pengalaman-pengalaman yang telah lalu untuk digunakan lagi dalam menyelesaikan persoalan budidaya. Menurutnya, anggota-anggotanya lebih mudah belajar turun langsung ke lahan dengan metode praktek sehingga anggota lebih mudah memahami materi yang disampaikan pada saat pertemuan rutin kelompok.

\section{Keaktifan Kelompok}

Kegiatan belajar Pokdakan Aci Bahari berupa pertemuan rutin satu bulan sekali ini selalu dibina oleh Pihak Dinas Perikanan Kabupaten Probolinggo, sehingga terdapat penyuluh perikanan yang diturunkan oleh pihak Dinas Perikanan untuk terus memantau perkembangan kelompok Aci Bahari ini serta membantu permasalahan yang dialami oleh kelompok. Penyuluh 
perikanan tersebut memang tidak ada jadwal tetap untuk mengunjungi Pokdakan Aci Bahari tetapi setiap ada kesempatan dan dibutuhkan, saat pertemuan rutin, pihak penyuluh selalu hadir.

Banyak kegiatan-kegiatan yang dilakukan oleh Pokdakan Aci Bahari selain pertemuan rutin, ada pula pelatihan diluar kota untuk mengasah kemampuan dalam berbudidaya. Progress atau kinerja kelompok yang dihasilkan dinilai sudah cukup baik dibandingkan dengan kelompok pembudidaya yang lain sehingga Dinas Perikanan memberikan kepercayaan besar kepada Pokdakan Aci Bahari dalam menerima bantuan yang akan diberikan pada awal tahun 2019. Pokdakan Aci Bahari telah cukup aktif dalam proses belajar karena hal tersebut terbukti dengan adanya prestasi yang diraih oleh Pokdakan Aci Bahari selama 5 tahun berdiri. Bapak ketua Pokdakan menerangkan pula bahwa Pokdakan Aci Bahari kerap meraih beberapa prestasi, diantaranya adalah turut berpartisipasi dalam lomba budidaya ikan air payau pada tahun 2017 yang diselenggarakan oleh Dinas Perikanan Kabupaten Probolinggo dan meraih juara satu seKabupaten Probolinggo.

\section{Peran Pokdakan Aci Bahari Sebagai Wahana Kerjasama}

Menurut Arimbawa dalam Sudarko (2010) menyimpulkan bahwa peran kelompok sebagai wahana kerjasama anggota berkategori tinggi. Peran kelompok sebagai wahana kerjasama meliputi kerjasama dalam pencarian informasi usahatani, kerjasama dalam pencarian komoditi, faktor produksi dan informasi pasar dan kerjasama dalam manajemen usahatani. Peran kelompok sebagai wahana kerjasama diartikan kelompok sebagai wadah untuk mempererat kerjasama diantara petani dalam kelompok dan antar kelompok dengan pihak lain untuk menghadapi berbagai ancaman tantangan, hambatan dan gangguan pada pra panen, pasca panen, pemasaran dan pemupukan modal sehingga petani mempunyai daya tawar yang baik.

Pokdakan Aci Bahari selalu melakukan kerjasama yang baik dalam setiap kegiatannya seperti pada saat menyusun diskusi belajar, budidaya usahatani dan kerjasama dalam berbagai hal lainnya yang dibutuhkan. Kerjasama yang baik di Pokdakan Aci Bahari dapat menghasilkan produksi ikan yang tinggi dan juga mencapai keuntungan. Apabila tidak ada kerjasama yang baik, maka produksi ikan bandeng akan kurang tinggi dan Pokdakan Aci Bahari tidak lagi berkembang. Berikut penjabaran hasil penelitian dari peran pokdakan sebagai wahana kerjasama.

\section{Suasana Kerjasama Kelompok}

Menurut Soekanto (1982) menyatakan bahwa kelompok sosial atau "social group" adalah himpunan atau kesatuan-kesatuan manusia yang hidup bersama, oleh karena adanya hubungan antara mereka. Hubungan tersebut antara lain menyangkut hubungan timbal-balik yang saling mempengaruhi dan juga suatu kesadaran untuk saling menolong. Kerjasama dalam Pokdakan Aci Bahari sudah baik karena saling membantu antar anggota kelompok. Seperti halnya pada saat terjadi musibah tanggul jebol karena air laut pasang maka seluruh anggota siap membantu disaat itu juga.

Adapula kerjasama pada saat menjemur tambak dan juga panen ikan bandeng yang membutuhkan banyak orang untuk mengangkut jaring. Sehingga dengan adanya anggota dianggap menjadi salah satu pertolongan pertama pada saat terjadi musibah yang tidak diinginkan. Dalam Pokdakan Aci Bahari telah saling mengenal baik dan saling mempercayai antara satu dengan yang lainnya, hal ini dikarenakan kebanyakan petambak anggota Pokdakan bertempat tinggal di lingkungan dan di desa yang sama. Hal ini tentu saja memudahkan petambak dalam bekerjasama. Kerjasama yang dilakukan juga didasari atas keadaan yang sama yaitu untuk dapat meningkatkan hasil produksi ikan bandeng yang mereka budidayakan yang nantinya dapat menambah pendapatan para anggota Pokdakan Aci Bahari. 


\section{Pembagian Tugas Kelompok}

Menurut Ibrahim (2015) menyatakan bahwa peran merupakan seperangkat tingkah laku yang diharapkan oleh orang lain terhadap seseorang yang penting bagi struktur sosial masyarakat dan sesuai dengan kedudukannya dalam suatu jabatan. Seseorang melaksanakan hak dan kewajiban berarti telah menjalankan suatu peran. Pembagian tugas kelompok adalah hal terpenting dalam adanya organisasi terutama kelompok tani karena di dalam kelompok terdapat struktur organisasi yang tersusun dari awal pembentukan organisasi tersebut. Pada Pokdakan Aci Bahari ini memiliki susunan struktur organisasi, yang terdiri dari ketua kelompok, sekretaris, bendahara dan anggota.

Dari 8 orang anggota Pokdakan, Aci Bahari terdapat struktur kelompok organisasi yang terdiri dari Bapak Haji Wahid selaku ketua Pokdakan, Bapak Nur Kamal selaku sekretaris, dan Bapak Abdul Ghofur selaku bendahara. Pembagian tugas yang dilakukan di Pokdakan Aci Bahari ini sudah cukup adil dan merata dikarenakan telah sesuai dengan porsi jabatan yang telah diberikan. Untuk tugas ketua kelompok adalah mengarahkan tugas yang harus diselesaikan oleh anggotanya agar dapat lebih disiplin dan tanggung jawab dalam menyelesaikan pekerjaan.

Pokdakan Aci Bahari juga sering menyusun proposal yang akan dikirimkan ke Dinas Perikanan, proposal tersebut berisi permohonan persetujuan kerjasama dalam hal bantuan seperti sarana produksi yang diperlukan untuk berbudidaya ikan bandeng. Tugas penyusunan proposal tersebut dikerjakan oleh ketua kelompok Bapak Wahid dan dibantu dengan sekretaris Bapak Nur Kamal. Tugas dari sekretaris adalah mengurus keluar masuknya surat, baik undangan surat untuk pertemuan rutin dengan Dinas dan lain sebagainya.

Kemudian tugas bendahara di Pokdakan Aci Bahari ini adalah mencatat segala bentuk pemasukan dan pengeluaran keuangan didalam proses kegiatan berbudidaya, seperti iuran kas anggota bulanan atau pengeluaran untuk pembelian alat-alat bersama, dan lain sebagainya. Sedangkan anggota kelompok mendukung dan juga membantu segala sesuatu yang sudah disusun dan diatur oleh ketua kelompok. Apabila ada kesulitan maka anggota lain pun harus mengingatkan dan memberikan saran-saran kepada ketua kelompok, pada intinya saling membantu sama lain. Antara ketua dengan sekretaris dan bendahara yang telah melaksanakan tugasnya masing-masing.

\section{Musyawarah Kelompok}

Musyawarah kelompok adalah perundingan bersama antara dua orang atau lebih untuk mendapatkan keputusan yang terbaik. Musyawarah adalah pengambilan keputusan bersama yang telah disepakati dalam memecahkan suatu masalah. Cara pengambilan keputusan bersama dibuat jika keputusan tersebut menyangkut kepentingan orang banyak atau masyarakat. Sama halnya dengan yang terjadi dalam Pokdakan Aci Bahari yang juga melakukan musyawarah untuk memecahkan permasalahan yang ada. Musyawarah kelompok yang sering dilakukan ialah pada saat terjadi masalah gangguan budidaya baik itu masalah hama dan penyakit yang menyerang ikan bandeng dan juga masalah cuaca.

Kemudian ketika terjadi kesalahpahaman antar anggota Pokdakan Aci Bahari, maka akan segera dibicarakan dan dimusyawarahkan bersama untuk mencapai tujuan yang diinginkan. Apabila terjadi suatu permasalahan di dalam kelompok maka akan segera ditangani bersama dan langsung dibicarakan bersama-sama dengan cara musyawarah kelompok yang selalu diadakan di tambak dan berdiskusi. Diskusi lainnya juga dilakukan Aci Bahari ke kelompok pembudidaya lain di Desa Curahsawo. Masalah yang diselesaikan yaitu masalah budidaya dan teknologi seperti permasalahan bagaimana cara agar hasil produksi ikan bandeng dapat meningkat. Sedangkan masalah teknologi adalah mengenai bagaimana aliran informasi mengenai teknologi baru dapat diserap oleh kelompok dan dapat diaplikasikan agar dapat meningkatkan produksi dan produktivitas. 


\section{Perencanaan Penyediaan Sarana Produksi}

Perencanaan penyediaan sarana produksi usahatani sangat diperlukan dalam proses budidaya ikan bandeng. Oleh karena itu, perlu dilakukan suatu perencanaan yang baik agar sarana produksi yang dibutuhkan kelompok dapat selalu tersedia terutama pada saat alat tersebut dibutuhkan. Perencanaan penyediaan sarana produksi oleh Pokdakan Aci Bahari dalam usahatani bandeng dinilai sudah cukup teratur dikarenakan Pokdakan Aci Bahari telah menjalin kerjasama dengan pihak penyedia sarana produksi. Kerjasama ini dimaksudkan untuk membantu anggota untuk mendapatkan bibit ikan bandeng yang mutu dan kualitasnya bagus dan juga untuk mendapatkan bibit dengan harga yang terjangkau serta mempermudah anggota dalam memasarkan hasil panennya. Kegiatan kerjasama ini terjalin atas dasar suatu hubungan yang saling membutuhkan baik bagi kelompok maupun pihak penyedia sarana dan jasa pertanian, dan juga didasari atas rasa saling percaya terhadap para pelaku kerjasama.

\section{Kerjasama Dengan Pihak Lain}

Kerjasama dengan pihak lain sangat diperlukan dalam keberhasilan kegiatan usahatani. Pihak-pihak tersebut akan memudahkan akses kelompok untuk memasarkan hasil produksinya dengan jalinan kemitraan atau dengan jalinan relasi yang cukup kuat menyebabkan terbentuknya rasa percaya antar dua pihak dan terjadi kesepakatan yang sama-sama menguntungkan. Kerjasama yang dilakukan oleh Pokdakan Aci Bahari yaitu hanya bekerja sama dengan pihak tengkulak dan pedagang, baik itu pedagang bibit maupun pedagang besar ikan bandeng di pasar.

Pokdakan Aci Bahari tidak menjalin kemitraan dengan perusahaan atau UKM tertentu tetapi kemitraan atau kerjasama yang dilakukan oleh Pokdakan Aci Bahari hanya dengan tengkulak dan pedagang bibit/ikan bandeng. Untuk penjualan ikan bandeng, Pokdakan Aci Bahari telah memiliki tengkulaknya masing-masing yang langsung datang ke tambak untuk membeli ikan bandeng hasil panen yang oleh tengkulak tersebut kemudian dipasarkan ke pedagang besar di pelabuhan Tempat Pelelangan Ikan (TPI) Mayangan Kota Probolinggo. Terjadi kesepakatan harga antara petambak dengan tengkulak mengenai harga jual. Akan tetapi kesepakatan harga tersebut tentu disepakati oleh kedua belah pihak. Sehingga terjadi hubungan kepercayaan yang baik antara petambak dan tengkulak yang datang.

\section{Peran Pokdakan Aci Bahari Sebagai Unit Produksi}

Menurut Garungan dalam Astuti (2010) menyatakan bahwa kelompok adalah suatu kesatuan sosial yang terdiri dari dua atau lebih individu yang telah mengadakan interaksi sosial yang cukup intensif dan teratur, sehingga diantara individu-individu itu sudah terdapat pembagian tugas, struktur dan norma tertentu yang khas bagi kesatuan sosial tersebut. Sedangkan kelompok tani adalah sekumpulan petani yang mempunyai kepentingan bersama dalam usahatani, bersifat non formal dan dilandasi oleh kesadaran bersama dan asas kekeluargaan.

\section{Pengambilan Keputusan}

Pengambilan keputusan dalam pengembangan produksi ikan bandeng oleh Pokdakan Aci Bahari dilaksanakan dengan cukup baik. Pokdakan Aci Bahari telah beberapa kali melakukan kegiatan yang bertujuan untuk mengembangkan produksi yang dirasa mampu menguntungkan dalam bidang teknologi, sosial, sarana produksi, dan menggunakan sumberdaya yang sudah tidak digunakan seperti limbah tetes tebu yang dihasilkan oleh pabrik gula menjadi bahan campuran bahan untuk memperbesar pertumbuhan ikan bandeng agar hasilnya lebih bagus selama masa pemeliharaan ikan bandeng. Informasi pemanfaatan dan pengembangan teknologi tersebut, mereka peroleh melalui kegiatan pertemuan rutin yang diadakan oleh Dinas Perikanan 
maupun ketika kelompok menghadiri seminar mengenai cara budidaya ikan yang baik dan benar.

Pokdakan Aci Bahari memperoleh informasi mengenai pembaharuan teknologi baru melalui interaksi antar petani yang kemudian dibantu oleh Dinas Perikanan dalam mewujudkan tersedianya fasilitas teknologi tersebut. Contoh kegiatan yang dilakukan oleh Pokdakan Aci Bahari adalah pemanfaatan tetes tebu dari PG Wonolangan untuk digunakan sebagai bahan campuran vitamin untuk pembesaran ikan bandeng dan udang berus agar ukurannya lebih besar, kemudian kegiatan yang kedua adalah dengan pengurangan pupuk kimia dalam pengolahan tanah agar subur bagi ikan bandeng.

Dalam pemberian pakan ikan bandeng, tidak menggunakan pakan buatan melainkan menggunakan pakan alami (klekap) yang memang sudah muncul dari hasil pengolahan tanah yang benar. Kemudian ada pengembangan produksi yaitu udang berus yang didapatkan dari hasil proses budidaya ikan bandeng, udang berus tidak berbibit tetapi ini muncul sendiri.

\section{Penyusunan Kebutuhan}

Penyusunan kebutuhan kelompok adalah salah satu peran yang cukup penting bagi suatu kelompok agar dapat mempermudah kelompok dalam penyediaan akan sarana dan prasarana dalam menunjang kegiatan anggotanya sehingga dapat meningkatkan skala ekonomis usaha yang dijalankan oleh kelompok tersebut. Untuk kebutuhan kelompok dapat dinilai baik dalam hal kerjasama pemenuhan kebutuhan kelompok yang dapat menunjang dalam proses budidaya bandeng karena sebelum memenuhi kebutuhan kelompok tersebut selalu melakukan diskusi bersama. Kebutuhan Pokdakan Aci Bahari disusun untuk menentukan kegiatan apa yang harus dilakukan oleh kelompok ke depannya, sehingga nantinya kelompok dapat lebih terarah dan berjalan dengan baik kegiatan yang akan dilakukan oleh Pokdakan Aci Bahari adalah hal-hal yang berkaitan dengan budidaya ikan bandeng. Kebutuhan Pokdakan Aci Bahari juga segala hal yang berkaitan dengan kebutuhan fasilitas dan teknologi.

\section{Fasilitas Teknologi}

Dalam hal penyediaan fasilitas dan teknologi, kemampuan kelompok dalam memfasilitasi penerapan teknologi (bahan, alat, cara) bagi anggota kelompok sudah dinilai cukup baik. Hal tersebut terlihat dari tersedianya bahan berupa bibit yang diperoleh dari pedagang di Desa Klaseman dan alat-alat yang digunakan dalam proses budidaya telah cukup disediakan untuk mempermudah kegiatan budidaya. Fasilitas teknologi alat yang dibutuhkan oleh kelompok telah difasilitasi dengan cukup baik. Fasilitas teknologi yang digunakan berasal dari program bantuan Dinas Perikanan berupa timbangan digital yang berfungsi untuk menimbang berat pupuk yang akan ditabur ke tambak, jenset, alat pengukur $\mathrm{PH}$ tanah dan alat pengukur kadar garam (salinasi).

\section{Pelaksanaan Kesepakatan}

Kemudian beralih mengenai kesepakatan kelompok Pokdakan Aci Bahari yang harus disepakati dan disetujui oleh seluruh anggota kelompok adalah yang pertama, masalah fasilitas teknologi (alat) milik kelompok yang tidak diperbolehkan untuk dijual ke oranglain dengan alasan apapun dan apabila ada anggota yang melanggar harus bersedia dikeluarkan dari Pokdakan Aci Bahari. Kesepakatan tersebut dibuat untuk menghindari adanya kecurangan anggota sehingga fasilitas kelompok tidak disalah gunakan. Kemudian kesepakatan kedua adalah masalah laporan data hasil produksi tiap panen agar memudahkan penyerahan laporan data produksi ke pihak Dinas Perikanan.

\section{Keberlanjutan Produksi}

Setelah adanya evaluasi kegiatan maka diperlukan suatu upaya demi keberlanjutan suatu produksi usahatani. Keberlanjutan produksi yang dilakukan yaitu dapat dalam bentuk upaya 
kelompok dalam melestarikan lingkungan dan peduli lingkungan. Dalam Pokdakan Aci Bahari, cukup berperan dalam peningkatan keberlanjutan produksi. Hal ini ditandai dengan adanya pemanfaatan limbah tetes tebu untuk campuran vitamin yang berguna untuk memperbesar ukuran ikan bandeng. Tetes tebu ini juga sebagai pengganti obat-obatan penumbuh yang berbahan dasar kimia.

Pokdakan Aci Bahari juga telah banyak mengikuti pelatihan seminar yang bertema pelestarian lingkungan budidaya agar produksinya tetap berlanjut di masa depan seperti teknik pengolahan tanah yang baik, penggunaan dosis pupuk yang tidak merusak tanah, dan penggunaan limbah tetes tebu untuk vitamin pembesaran ikan. Adapun beberapa upaya yang dilakukan mencakup harapan Pokdakan Aci Bahari untuk keberlanjutan produksinya agar dapat lebih meningkat dari segi kualitas maupun kuantitas.

\section{SIMPULAN}

Peran Kelompok Pembudidaya Ikan (Pokdakan) Aci Bahari di Desa Pesisir Kecamatan Gending ada 3, yaitu peran kelompok sebagai kelas belajar, wahana kerjasama dan unit produksi. (1) Peran Pokdakan Aci Bahari sebagai kelas belajar meliputi perumusan kebutuhan belajar, motivasi belajar, pertemuan rutin kelompok, kerjasama proses belajar dan keaktifan kelompok, (2) peran Pokdakan Aci Bahari sebagai wahana kerjasama meliputi suasana kerjasama, pembagian tugas, musyawarah kelompok, penyediaan sarana produksi dan kerjasama dengan pihak lain, (3) peran Pokdakan Aci Bahari sebagai unit produksi meliputi cara pengambilan keputusan, penyusunan kebutuhan kelompok, fasilitas teknologi, pelaksanaan kesepakatan kelompok dan peningkatan keberlanjutan produksi.

\section{DAFTAR PUSTAKA}

Andrianto, T. 2005. Pedoman Praktis Budidaya Ikan Kerapu Macan. Yogyakarta : Absolut.

Astuti, Nur A. 2010. Analisis Efektivitas Kelompok Tani di Desa Gatak Kabupaten Sukoharjo. Skripsi. Fakultas Pertanian : Universitas Sebelas Maret Surakarta.

Benne, K.D and P. Sheats. 1948. Functional Roles of Group Members. Journal of Social Issues. $4(2): 41-49$

Bungin, B. 2007. Penelitian Kualitatif. Jakarta : Prenada Media Group.

Dinas Perikanan dan Kelautan Provinsi Jawa Timur. 2015. Statistik Budidaya Provinsi Jawa Timur Tahun 2015. Probolinggo : Dinas Perikanan dan Kelautan Provinsi Jawa Timur.

Forsyth, D.R 2010. Group Dynamics. University Of Richmond : Pre-Press PMG.

Ibrahim. 2015. Metodologi Penelitian Kualitatif. Bandung: Alfabeta.

Satori, Djam'an dan Aan Komariah. 2014. Metodologi Penelitian Kualitatif. Bandung : Alfabeta

Soekanto, Soerjono. 1982. Sosiologi Suatu Pengantar. Yogyakarta : PT. Rajagrafindo Persada.

Sudarko. 2010. Hubungan Dinamika dan Peran Kelompok Dengan Kemampuan Anggota Dalam Penerapan Inovasi Teknologi Usahatani Kopi Rakyat. (Kasus di Desa Sidomulyo 
Kecamatan Silo Kabupaten Jember. Tesis. Sekolah Pasca Sarjana : Institut Pertanian Bogor.

Sugiyono. 2014. Metode Penelitian Kuantitatif, Kualitatif, dan R\&D. Bandung : Alfabeta.

Sulistiani, Novi. 2011. Identifikasi Kebutuhan Belajar Gelandangan Remaja di Kawasan Pasar Johar Semarang. Skripsi. Fakults Ilmu Pendidikan : Universitas Negeri Semarang.

Putri, T.A., 2015. Analisis Keberlanjutan dan Peran Kelembagaan Kelompok Tani Sapi Perah Terhadap Pendapatan Anggota Kelompok. Skripsi. Fakultas Ekonomi dan Manajemen: Institut Pertanian Bogor. 